\title{
KOMIK SEBAGAI MEDIA PEMBELAJARAN MATEMATIKA BAGI SISWA SEKOLAH DASAR
}

\author{
Nurhayati, Aswar, Irfan Arifin \\ Desain Komunikasi Visual, Fakultas Seni dan Desain UNM \\ aswar_saini@yahoo.co.id \\ irfan.arifin@unm.ac.id
}

\begin{abstract}
Abstrak
Perancangan komik media pembelajaran matematika ini dilatarbelakangi oleh rendahnya tingkat pengetahuan Matematika di Indonesia. Dalam pelajaran Matematika Perkalian merupakan dasar atau awal mula berlatih berpikir kritis dan sistematis, sehingga apabila konsep perkalian dipahami dengan baik, akan mudah melanjutkan ketingkat matematika selanjutnya. Perancangan ini bertujuan agar siswa lebih termotivasi untuk belajar matematika. Perancangan ini menggunakan metode pengumpulan data berupa observasi, wawancara, studi pustaka, dan dokumentasi. Konsep desain dalam perancangan ini adalah "praja muda karana" dari konsep tersebut dihasilkan sebuah buku komik media pembelajaran Matematika bagi siswa kelas 2 Sekolah Dasar.
\end{abstract}

Kata kunci: edukasi, matematika, perkalian, perancangan komik

\section{PENDAHULUAN}

Matematika merupakan ilmu yang memiliki peranan penting bagi kemajuan peradaban manusia. Dan sebagai warga negara Indonesia yang berhak untuk mendapatkan pendidikan seperti yang tertuang dalam UUD 1945 , tentunya harus memilik i pengetahuan umum minimum. Pengetahuan umum minimum itu di antaranya adalah matematika. Seperti diperjelas dalam UU nomor 20 tahun 2013 BAB III pasal 4 ayat 5 pendidikan diselenggarakan dengan mengembangkan budaya membaca, menulis dan berhitung bagi segenap warga masyarakat. Salah satu yang disebutkan adalah berhitung yakni matematika itu sendiri.

Dalam dunia pendidikan, pelajaran matematika menjadi pelajaran yang sangat penting, karena pelajaran matematika mengajarkan tentang bagaimana cara berpikir dan mengolah logika yang digunakan untuk memecahkan masalah sehari- hari. Hal ini sesuai dengan pandangan (Erman, 2003: 298). Contohnya seperti berdagang, menghitung jumlah mata uang, mengetahui angka romawi pada petunjuk arah jalan, pengukuran tanah, pelukisan, konstruksi, astronomi dan membantu dalam mengembangkan disiplin ilmu lain. Dengan mempelajari matematika seseorang terbiasa berpikir secara sistematis, ilmiah, menggunakan logika, kritis serta dapat meningkatkan daya kreativitas. $\mathrm{O}$ leh sebab itu, matematika wajib diperkenalkan dan diajarkan sejak dini bagi anak Sekolah Dasar untuk mencapai tujuan satuan pendidikan yang tertuang dalam Kurikulum 2013 Sekolah Dasar yaitu "berilmu, cakap, kritis, kreatif dan inovatif.

Salah satu bagian pelajaran dalam mata pelajaran matematika dalam kurikulum Sekolah Dasar adalah perkalian. Konsep perkalian merupakan salah satu konsep dasar matematika, yang mana perkalian adalah penjumlahan yang berulang, inilah yang menyebabkan $\mathrm{AxB}$ berbeda dengan $\mathrm{BxA}$, sebab $A x B=B+B+B+B$ (sebanyak $A x$ ), sedangkan $B x A=A+A+A+A$ (sebanyak $B x)$.

Pada kenyataannya masih banyak yang tidak mengerti perbedaan pengertian antara $\mathrm{AxB}$ dengan $\mathrm{BxA}$, dengan alasan menghasilkan angka akhir yang sama karena sifat Komutatif pada operasi bilangan bulat. Di mana tidak adanya kesadaran bahwa sifat Komutatif ini hanya berorientasi pada hasil akhir, sedangkan pada konsep keduanya berbeda. Seperti sebuah kasus yang pernah terjadi dan menghebohkan media sosial beberapa waktu yang lalu mengenai perdebatan $4 \times 6$ atau $6 \times 4$.

Dalam belajar Matematika, ada dua macam pengetahuan yang berbeda: 1) Pengetahuan Prosedural, dan 2) Pengetahuan Konseptual. Pengetahuan prosedural adalah pengetahuan yang berkaitan dengan simbol- 
simbol, bahasa dan aturan operasi perhitungan. Sedangkan pengetahua $n$ konseptual adalah pemahaman terhadap konsep dasar dari operasi perhitungan tersebut. Mengingat pentingnya dua macam pengetahuan tersebut maka diperlukan media yang dapat medukung pembelajaran. Media adalah segala alat fisik yang dapat menyajikan pesan serta merangsang siswa untuk belajar (briggs). Hal ini sangat membantu guru dalam mengajar dan memudahkan siswa menerima dan memahami pelajaran. Proses ini membutuhkan guru yang mampu menyelaraskan antara media pembelajaran dan metode pembelajaran. Pemakaian media pembelajaran dalam proses belajar mengajar juga dapat membangkitkan keinginan dan minat yang baru bagi siswa, membangkitkan motivasi belajar. Pada kenyataannya Masih banyak Sekolah-Sekolah yang hanya mementingkan aspek kognitif saja dan kurang memandang persoalan motivasi belajar siswa. Identifikasi penyebab masalah dalam pembelajaran mengenai kurangnya motivasi belajar peserta didik di dalam melakukan pembelajaran antara lain (1) monotonnya proses pembelajaran di dalam Sekolah, (2) Kurang maksimalnya di dalam penggunaan alat ataupun media pembelajaran yang menjadi pendukung di dalam aktivitas belajar - mengajar. Beberapa yang cenderung menjadi hambatan otomatis anak akan kehilangan minat belajar yang optimal. (samadaranta.wordpress.com.2010).

Berbicara mengenai media pembelajaran. Saat ini, perkembangan media sudah sangat pesat dan telah menjadi inovas $i$ baru dalam dunia pendidikan. Tidak terkecuali bagi perkembangan media grafis. komik adalah salah satu di antara banyaknya media pembelajaran. Komik merupakan salah satu media grafis yang digunakan dalam dunia pendidikan serta bacaan bergambar yang mengandung berbagai muatan pesan yang memiliki daya tarik bagi kalangananak -anak. berfungsi sebagai alat memperjelas materi, menciptakan nilai rasa lebih dalam memahami materi, menarik minat dan perhatian anak, serta membangkitkan rasa ingin tahu anak. Hal ini tentu dapat menjadi salah satu solusi dalam proses belajar mengajar menjadi lebih efektif.

Ada beberapa jenis komik seperti komik strip yang biasa kita temukan dalam majalah atau surat kabar, kemudian jenis komik yang dikemas dalam bentuk buku, dan saat ini yang sering kita jumpai di media sos ial berbentuk komik online yang teknik penggarapannya bervariasi baik manual maupun secara digital. Komik online yang sering dijumpai lebih banyak dalam bentuk meme yang salah satunya menggunakan program comic life. Komik dengan penggarapan comic life cenderung menggunakan visual dari foto-foto objek manusia sebagai ilustrasinya. Maka dari itu penelitian ini mencoba untuk membuat media pembelajaran dalam bentuk komik edukasi dengan tampilan visual yang akan disajikan lebih menarik. Dengan rumusan masalah "Bagaimana merancang media pembelajaran matematika yang menarik dan tidak membosankan bagi siswa SD kelas 2 dengan tetap mengacu pada buku pelajaran yang ada di Sekolah.

Dalam perancangan sebuah komik, tidaklah mudah banyak hal yang harus diperhatikan dan diketahui dimana Komik merupakan aliran pilihan yang berkesinambungan, yang terdiri dari pencitraan, alur cerita, dialog, gesture dan banyak pilihan lainnya.

Komik adalah sintesa unik atas katakata dan gambar, sebuah bentuk seni yang berbeda dengan kekuatan dan kekurangannya sendiri. Tidak seperti sinema atau film, gambarnya tidak bergerak. Dalam buku "Membuat Komik", ada dua hal dasar yang ingin dicapai dari komik, yaitu. Agar pembaca memahami cerita dan membaca cerita sampai selesai. (Gary Spencer Millidge)

Dave Gibbsons, dalam tulisannya sebagai pengantar buku Comic BookDesign (Watson Guptill Publications, 2009) menyatakan bahwa walaupun saat ini komputer menggantikan alat-alat gambar tradisional, namun tantangan yang di hadapi komikus tetap sama, yaitu menarik perhatian pembaca dan menjaganya.

Hal-hal yang perlu diperhatikan dalam pembuatan sebuah komik adalah sebagai berikut:

1. Menentukan tema cerita

Tema cerita dalam komik memegang peranan penting karena visualisasi dari tokoh utama yang diciptakan dan lainnya 
adalah tergantung dari tema cerita yang dibangun atau yang diinginkan.

2. Menciptakan tokoh cerita (karakter)

Pada bagian ini, imajinasi kita dituntut untuk benar-benar muncul mereferensikan apa yang pernah kita lihat, pikirkan dan lain-lain. Dimulai dengan menuliskan bentuk visual tokoh sesuai tema pilihan, kemudian kita harus mengenal sifat dari tokoh yang di ciptakan,

3. Gaya visual

Gaya visual atau gaya gambar akan menjadi aspek pertama yang ditemui pembaca. Ada beberapa jenis aliran gaya visual dalam pembuatan sebuah komik, yaitu cartoon style, semi cartoon style, realism style, dan fine art style.

4. Membuat naskah cerita

Dalam membuat naskah cerita, creator harus kritis dan memikirkan tentang struktur cerita atau kisah. Dalam struktur cerita atau kisah, cerita harus memiliki awal, akhir dan rentetan cerita yang menghubungkan keduanya.

5. Membuat sketsa kasar

Sketsa kasar adalah gambar gambar kasar, yang merupakan dasar dari gambar jadi. Dapat digambar dengan menggunakan pensil, disini kita dapat mengatur proporsi karakter, sudut pandang, background, dan lain- lain. Setelah sketsa kasar selesai kita sudah siap melakukan penintaan

6. Finishing

Setelah sketsa kasar selesai kita sudah siap melakukan penintaan, kemudian diberi lapisan penguat emulsi berupa fixative atau clear, agar tinta gambar lebih awet dan cat warna tidak dimakan serangga atau cepat pudar tertimpa cuaca.

7. Layout (tata letak)

Menurut Surianto Rustan (2009:0), layout dijabarkan sebagai tata letak elemenelemen desain terhadap suatu bidang dalam media tertentu untuk mendukung konsep/pesan yang dibawanya. Melayout adalah suatu proses/tahapan kerja dalam desain.

8. Tipografi

Tipografi memegang peranan penting dalam perancangan sebuah komik maupun dalam segala bentuk publikasi, karena kita harus tahu berapa ukuran tulisan yang akan kita gunakan, efek dan bentuk yang akan kita tampilkan sehingga muatan emosi dan sifat dari pesan yang muncul sesuai dengan tujuan komunikasi yang ingin kita sampaikan kepada publik.

9. Unsur Desain

Peranan pokok komik sebagai media pembelajaran menurut Sudjana dan Rivai (2002:68) adalah kemampuannya dalam menciptakan minat belajar siswa. Sebagai media audio visual, agar dapat berfungsi sebagaimana mestinya yaitu mengoptimalkan pembelajaran, maka dalam pengembangan komik harus berpegang pada beberapa unsur desain (Arsyad, 2006).

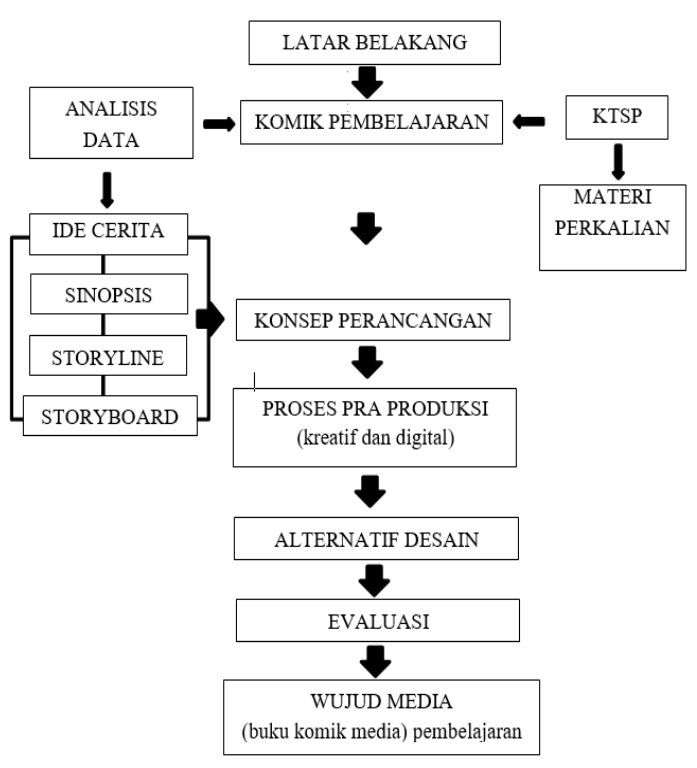

Gambar 1. Bagan Kerangka Pikir

\section{METODE}

Dalam proses pengumpulan data yang dilakukan peneliti, metode pengumpulan data yang digunakan yaitu metode pengumpulan data secara primer dan sekunder. Di mana peneliti melakukan penelitian dan observasi

langsung ke Sekolah kemudian didukung dari data sekunder dari buku-buku, jurnal dan artikel yang bersangkutan dengan materi yang akan diangkat.

\subsection{Konsep Desain}

Berdasarkan data awal yang sudah peneliti dapatkan, disimpulkan sebuah konsep desain yang akan menjadi acuan konsep 
perancangan yang akan dilakukan. Adapun konsep desainnya yaitu "praja muda karana" dimana ide ceritanya yaitu berlatar belakang sebuah perkemahan pramuka yang desainnya mengacu pada unsur sederhana, natural, dan lokal daerah.

Sederhana dan natural karena target audience- nya yaitu anak-anak umur 8-10 tahun agar komik pembelajaran yang akan dibuat lebih mudah diterima. selanjutnya mengandung unsur lokal karena diharapkan anak-anak sejak dini mengetahui tentang hal hal yang berhubungan dengan daerahnya

\subsection{Konsep dan Strategi komunikasi}

Seperti yang sudah dijelaskan sebelumnya mengenai analisa komunikasi dengan target audience siswa berumur 8-10 tahun dan setelah melakukan observasi mengenai ketertarikan anak di Sekolah S D Parang tambung 1 yang lebih menyukai cerita bergambar maka Pendeka tan yang dilakukan adalah dengan merancang buku komik dengan ide media yang sudah ditetapkan yaitu buku komik menggunakan teknik digital dengan menggunakan gambar Bitmap/Vector sebagai objek ilustrasinya yang menampilkan visual serta cerita yang menarik yang tetap merujuk pada materi dan tema dalam buku pelajaran matematika perkalian. sehingga materi serta media pembelajaran bisa berjalan berdampingan dan dapat mencapai tujuan yang diharapkan. Bahasa yang akan digunakan dalam komik adalah bahasa Indonesia seharihari atau informal. Hal ini untuk menyesuaikan karakteristik target audience anak-anak 8-10 tahun agar terbiasa menggunakan bahasa Indonesia seharihari, sekaligus untuk memudahkan pembaca dalam memahami cerita dan pesan-pesan yang ingin disampaikan.

\subsubsection{Kompetitor}

Dalam perancangan buku komik pembelajaran matematika ini, peneliti mencoba mencari kompetitor dengan tema yang sama yakni pembelajaran matematika. Dan kompetitor komik yang sedang beredar dipasaran adalah komik "asyik belajar matematika" yang sudah sampai edisi ke 8 .

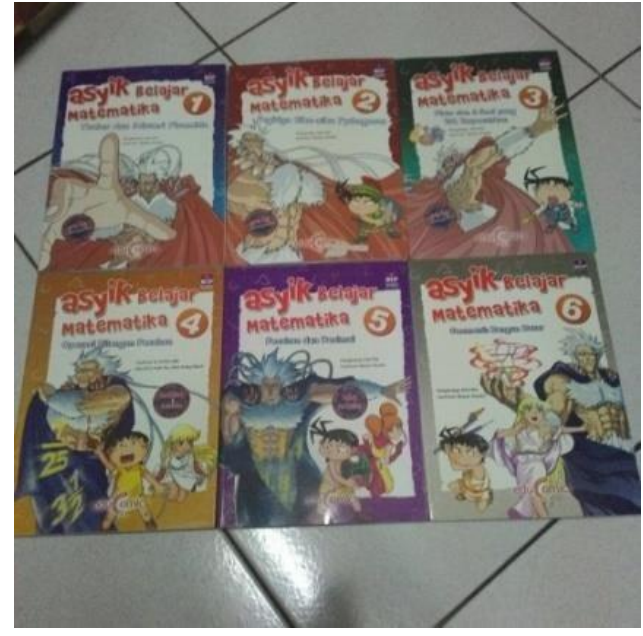

Gambar 2 Buku komik "Asyik belajar Matematika" edisi 1-8 (sumber :www.inzubooks.com)

\subsubsection{Differensiasi}

Dalam perancangan sebuah komik, cerita serta karakter setiap komik yang dibuat sangatlah bervariasi an berbeda-beda tergantung pada jenis komik yang dibuat. Yang membedakan komik ini dengan komik lainnya adalah pada materi yang dibahas lebih khusus demi mencapai tujuan untuk menyelesaikan masalah yang ada.

\subsection{Konsep dan Strategi Kreatif}

Pada perancangan buku komik media pembelajaran matematika ini, peneliti melakukan pendekatan dari segi cerita yang sederhana dan ringan untuk menyesuaikan dengan target audience yang berumur 8-10 tahun dan jenis komik yang digunakan juga berbeda seperti yang sudah dijelaskan sebelumnya.

\subsubsection{Rencana karakter tokoh komik}

Seiring dengan perkembangnya dunia teknologi, anak-anak sudah idak lazim lagi dengan yang namanya superhero seperti superman atau wonder women dan lain sebagainya, yang biasa mereka lihat di televisi maupun di media cetak seperti, poster film, Koran dll. Sebagian besar anak, sangat menyukai tokoh superhero. Kuat dan selalu membela kebenaran, banyak anak yang bahkan mengidolai tokoh-tokoh tersebut. Namun masih jarang mereka mengetahui tokoh tokoh superhero lokal pahlawan Indonesia maupun pahlawan dari Makassar itu sendiri. 
Jeff Greenberg, profesor psikologi sosial dari University of Arizona mengatakan bahwa superhero memberikan kekuatan pada anak- anak. Kekuatan tersebut dapat berupa panutan, tindakan, bahkan juga sudut pandang tertentu.

"Anak-anak masih membutuhkan perlindungan dari berbagai macam bahaya yang ada dipikiran mereka. Untuk itu mereka membutuhkan sosok yang dapa mereka andalkan secara utuh selain orang tua." (Greenberg CNN, Minggu 4/5/2014)

Berdasarkan penjelasan tersebut, peneliti akan merancang buku komik media pembelajaran matematika dengan menggunakan tokoh superhero lokal Indonesia pada umumnya dan Sulawesi Selatan pada khususnya untuk memperkenalkan tokohtokoh pahlawan yang ada di Indonesia terutama yang ada di Makassar. yang di desain sedemikian rupa agar sesuai dengan karakter visual yang cocok untuk target audiens siswa berumur $8-10$ tahun.

\subsection{Konsep dan Strategi Visual}

Berdasarkan analisis dan identifikasi data yang sudah dilakukan sebelumnya maka konsep strategi visual yang akan dibuat dalam perancangan buku komik sebagai media pembelajaran ini adalah sebagai berikut:

\subsubsection{Gaya visual (gaya gambar)}

Dari beberapa data mengenai macammacam gaya visual yang bisa digunakan dalam perancangan sebuah komik, maka peneliti mengidentifikasi bahwa semi Cartoon Style adalah gaya visual yang akan digunakan dalam perancangan buku komik ini.

\subsubsection{Warna}

Pada perancangan buku komik media pembelajaran ini, selain menggunakan teknik gaya visual semi Cartoon style, peneliti juga akan menggunakan berbagai warna. Berdasarkan analisa dan identifikasi warna yang sudah dilakukan maka peneliti akan menggunakan berbagai macam warna sesuai kebutuhan perancangan nantinya guna menghasilkan tampilan desain yang memiliki suasana ceria. Karena dalam penggunaan warna, anak-anak senang dengan semua warna. (Baptista,2007:06).

\subsubsection{Tipografi}

Dalam analisa pemilihan font, maka peneliti akan menggunakan beberapa alternatif font berikut yang akan diaplikasikan pada sampul dan juga isi dari buku komik yang akan dirancang.

\section{HASIL DAN PEMBAHASAN \\ 3.1. Pra Prancangan \\ 3.1.1. Brainstorming}

Dalam proses mencari ide atau brainstorming, peneliti memulai dengan menganalisis materi terkait pada media pembelajaran dalam berbagai media yang ada, dimulai dari media audio visual yang bisa di akses di youtube, buku komik maupun buku cer ita bergambar yang terdapat di Toko buku sampai game ios dan android yang membahas mengenai pembelajaran matematika perkalian serta berdiskusi dengan yang ahli dibidang Matematika. hasil dari analisa tersebut adalah mengenai materi sederhana yang bisa digunakan, ide mengenai simbolsimbol yang digunakan sebagai pengganti angka dalam menggambarkan soal-soal latihannya yang disesuaikan dengan target audience anak-anak yang sedang mempelajari pelajaran matematika tersebut artinya menggunakan visual yang mudah dimengerti oleh anak-anak sesuai lingkungannya, serta uk uran buku yang akan dirancang yaitu ukuran persegi $(20 \times 20 \mathrm{~cm})$. Analisis ini tentu saja harus disesuaikan dengan karakteristik peserta didik yang menjadi target audience dalam perancangan komik media pembelajaran ini, apakah benar-benar cocok dengan karakteristik dan kondisi peserta didik yang ada di Sekolah SD Parang tambung I. kemudian selanjutnya dikembankan menjadi suatu ide mengenai materi yang akan dimasukkan dalam perancangan komik media pembelajaran ini, serta akan dibawakan seperti apa materi dalam komik media pembelajaran ini. 


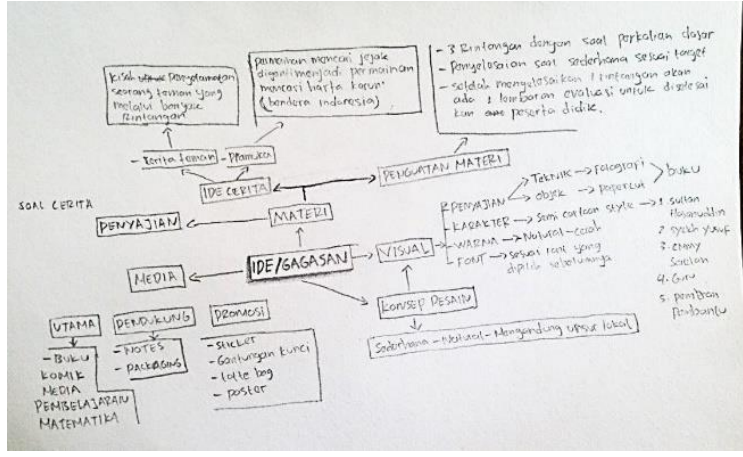

Gambar 3. Brainstrorming

\subsubsection{Tema cerita}

Seperti yang telah dijelaskan sebelumnya mengenai materi yang akan digunakan dalam komik media pembelajaran yang akan di rancang yaitu perkalian dasar bagi SD kelas dua. Maka berdasarkan hasil brainstrorming yang sudah dilakukan peneliti memuat dua ide tema cerita yakni tema bebas yang kuat dengan pertemanan dan persahabatannya dan juga tema pendidikan. Dan setelah menganalisis kedua ide tema tersebut, peneliti memutuskan untuk memilih tema pendidikan agar materinya lebih dekat dengan lingkungan sehari- hari target audience yang akan dikemas dalam sebuah ide cerita yang tetap mengarah pada materi perkalian yang akan diajarkan kepada peserta didik.

\subsubsection{Ide Cerita}

Berdasarkan analisis materi yang terdapat dalam buku pelajaran matematika peserta didik dalam materi perkalian, ada beberapa subbab yang diajarkan, namun peneliti hanya akan membahas mengenai subbab pertama yaitu pengenalan materi perkalian dari yang paling dasar, kemudian komik yang dirancang berperan untuk lebih menegaskan materi awal yang telah dibawakan oleh gurunya, sehingga diharapkan peserta didik bisa lebih mengerti dengan materi perkalian dasar sesuai dengan tujuan perancangan komik ini. Berdasarkan tema cerita yaitu pendidikan, selanjutnya ide cerita dari peneliti yaitu "mencari harta karun" cerita ini berlatar belakang sebuah perkemahan pramuka.

Sebelum memutuskan untuk mengangkat ide cerita berlatar perkemahan pramuka sebelumnya peneliti sudah melakukan analisis dan wawancara terhadap peserta didik mengenai pengetahuan mereka tentang pramuka. serta melakukan analisis mengenai kegiatan-kegiatan apa saja yang biasa dilakukan dalam kegiatan pramuka kemudian digabungkan dengan materi yang akan disajikan kepada peserta didik, dalam hal ini adalah materi perkalian dasar.

\subsubsection{Sinopsis "mencari harta karun?"}

Berdasarkan ide cerita yang telah dikemukakan peneliti diatas yakni "mencari harta karun" maka dari itu peneliti telah membuat sebuah sinopsis dari ide cerita yang akan dibuat yakni cerita dimulai dari sebuah perkemahan. terlihat 3 orang anak sedang berdiskusi mengenai peta yang ada ditangan salah satu dari mereka. Mereka bersama dengan peserta kemah lainnya berusaha untuk menemukan sebuah harta karun. Sanggupkah mereka menyelesaikan tantangan dan sampai ke tempat harta karun yang dimaksud.

\subsubsection{Deskripsi Karakter Tokoh}

Berdasarkan ide cerita yang telah dijelaskan sebelumnya, maka disimpulkan dalam perancangan ini peneliti menggunakan 6 tokoh karakter.

\subsection{Perancangan}

\subsubsection{Eksplorasi Visual dan Digitalisasi}

Acuan eksplorasi visual yang dilakukan berdasar pada konsep desain yang sudah dijelaskan sebelumnya yaitu sederhana, natural serta mengandung unsur lokal daerah. Berdasarkan karakter tokoh yang sudah dijelaskan sebelumnya, maka peneliti membuat alternatif sketsa karakter yang dilanjutkan ketahap digitalisasi sebagai berikut: 


\section{imajinasi}
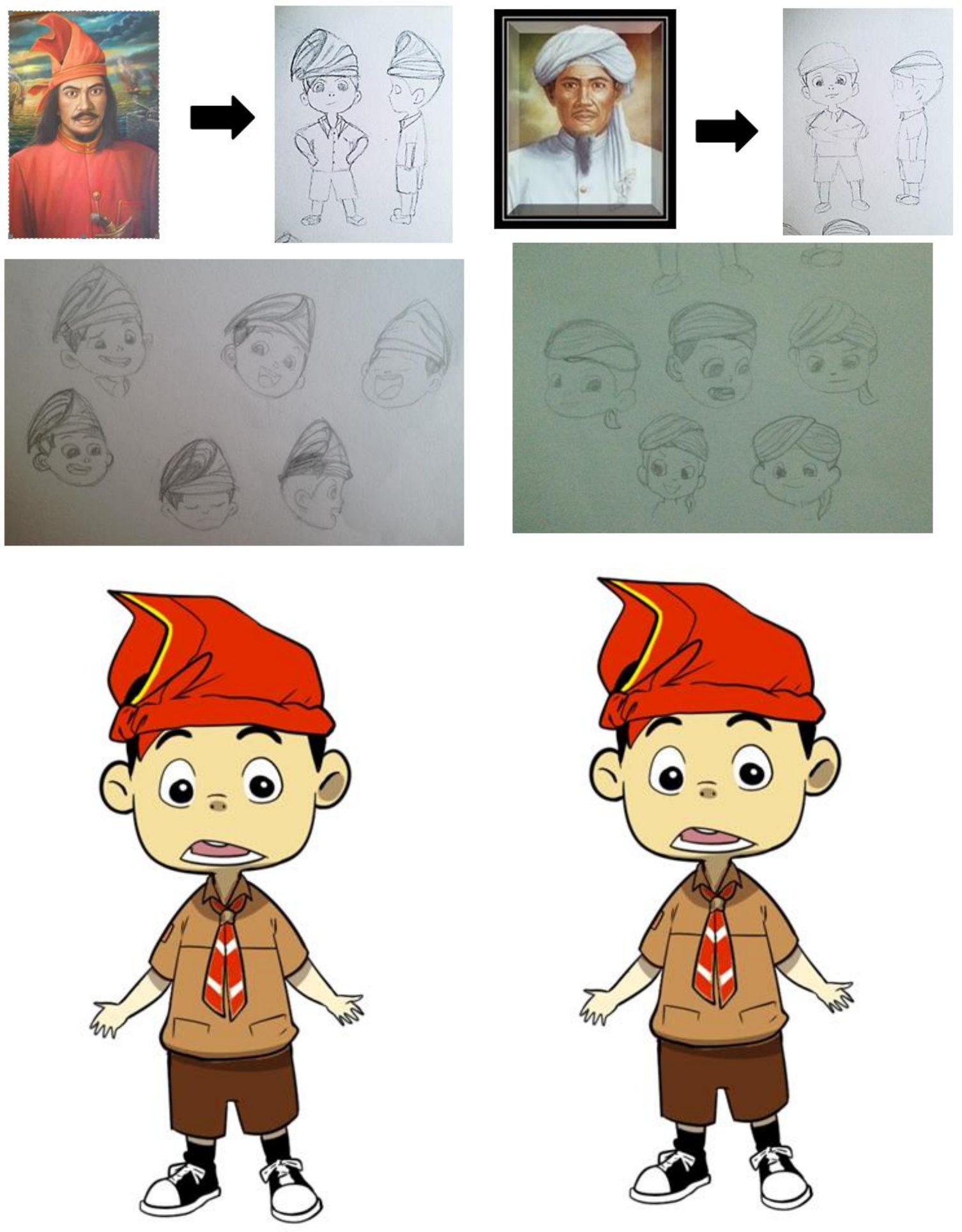

Gambar 4. Karakter Sultan

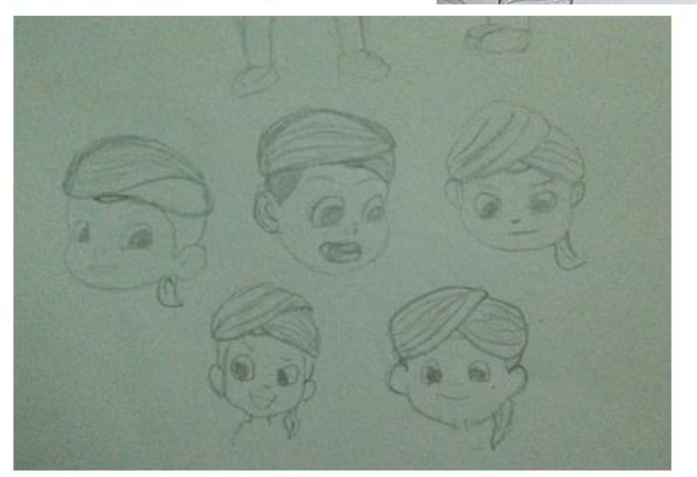

Gambar 5. Karakter Yusuf 

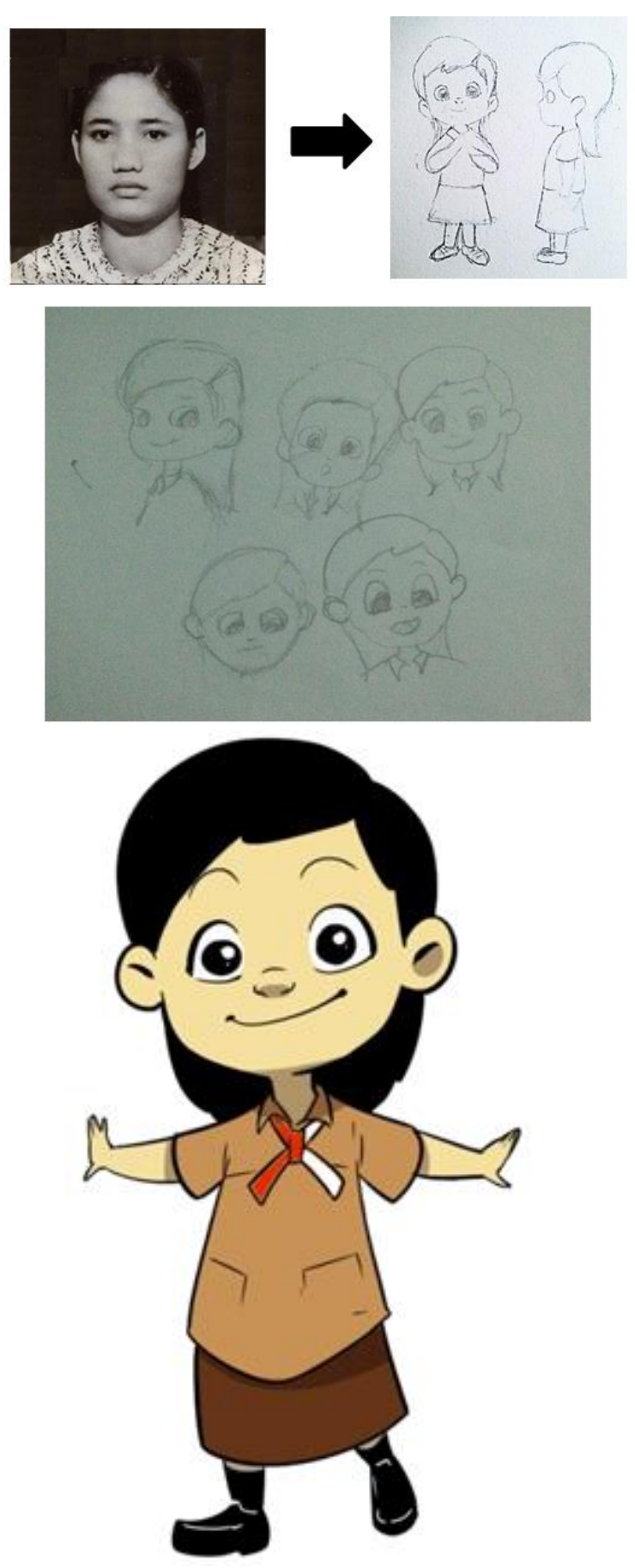

Gambar 6. Karakter Emmy
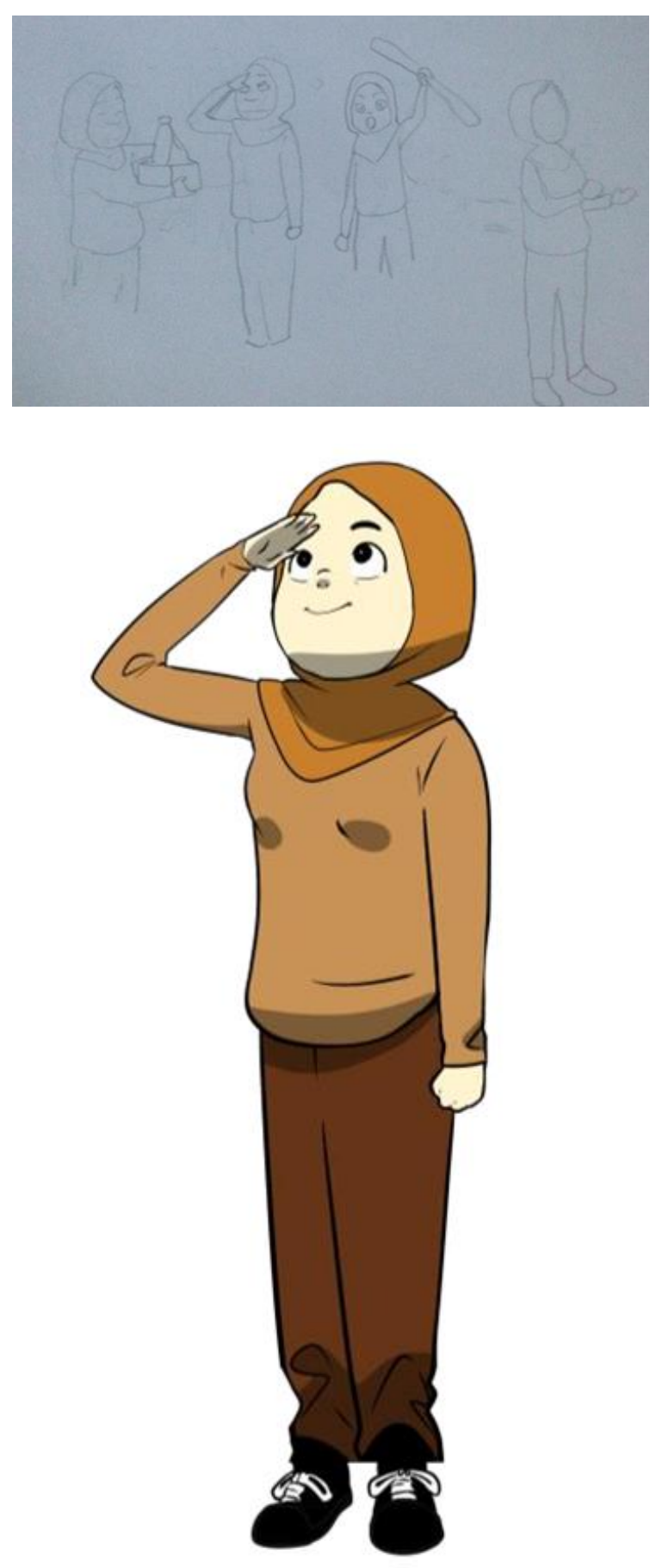

Gambar 7. Karakter Ibu guru 


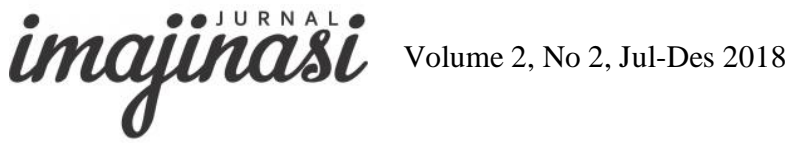
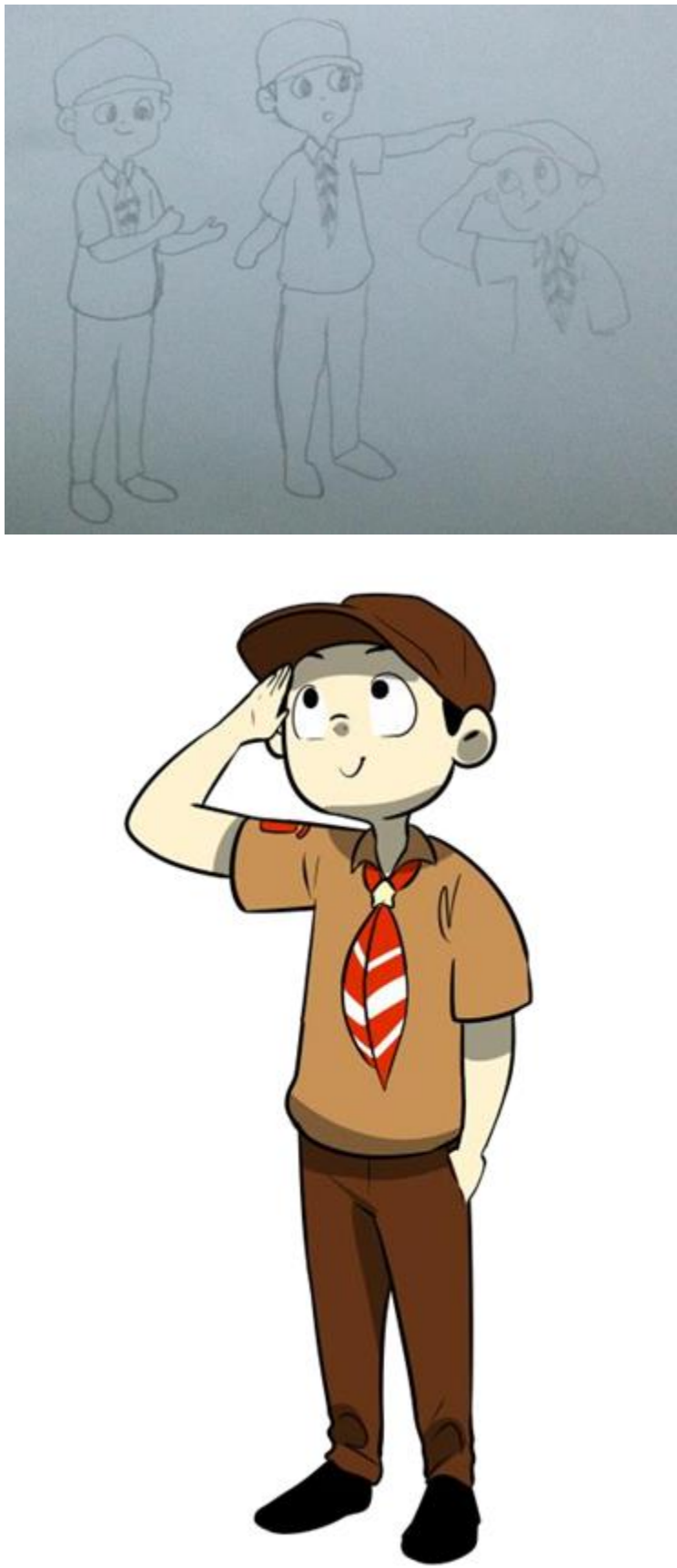

Gambar 8. Karakter Bapak guru

\subsubsection{Digitalisasi Tipografi}

Berdasarkan uraian analisa font serta pengajuan font yang sudah dilakukan sebelumnya, dan pada perancangan ini peneliti seluruhnya menggunakan font comic sans ms. Serta pada bagian judul dan tulisan yang ingin ditekankan, peneliti mendesain font sedemikian rupa sehingga terlihat lebih menarik dan tetap mengacu pada kondep desain sebe lumya. Seperti digambarkan sebagai berikut:

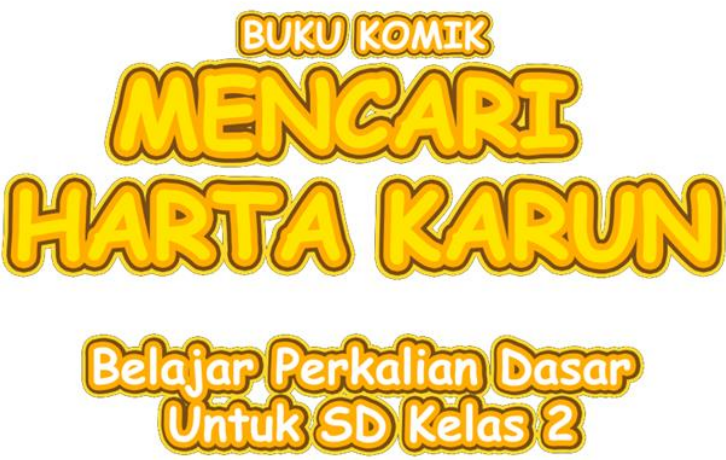

Gambar 9. Tipografi Judul Komik

\section{3. final perancangan}

Setelah melalui proses sketsa, serta digitalisasi maka hasil dari perancangan yang telah dilalui tersebut adalah sebagai berikut

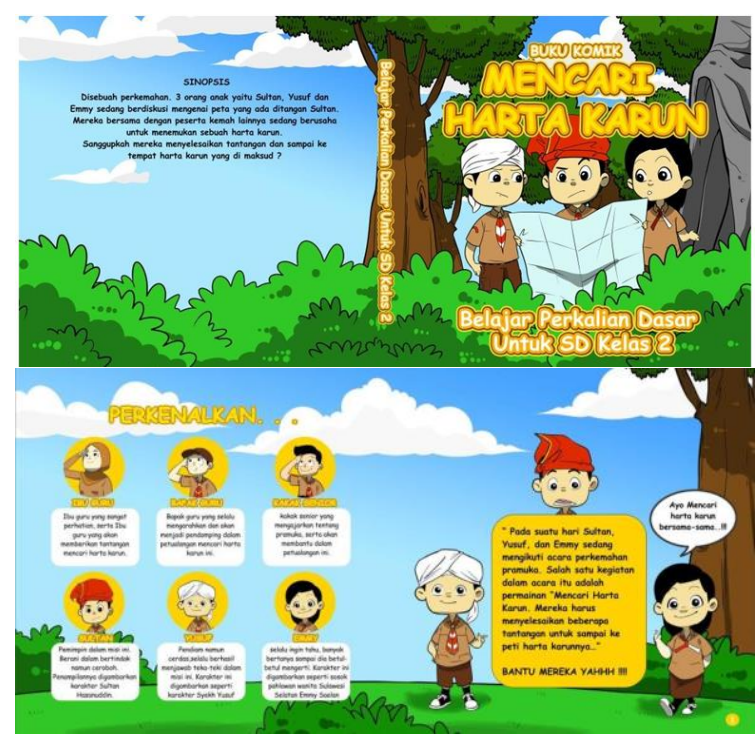

Gambar 10. Desain Isi Komik

\section{SIMPULAN DAN SARAN}

\subsection{Kesimpulan}

Perancangan Komik Media pembelajaran Matematika yang membahas materi perkalian ini, setelah melalui beberapa tahap konsep untuk mencari solusi dari masalah yang ada, hingga sampai pada hasil perancangan. Maka berdasarkan proses perancangan buku komik ini, dapat diambil kesimpulan sebagai berikut: 
1. Perkalian merupakan dasar atau awal mula berlatih berpikir kritis dan sistematis, sehingga apabila konsep perkalian dipahami dengan baik, akan mudah melanjutkan ketingkat matematika selanjutnya.

2. Konsep desain yang diangkat dalam perancangan ini yaitu "praja muda karana" dimana siswa diajak untuk belajar sambil bermain.

3. Sumber inspirasi tokoh dalam perancangan ini mengangkat tokoh pahlawan S ulawesi Selatan seperti S ultan Hasanuddin, Syekh Yusuf, dan Emmy Saelan. Serta tokoh pendukung seperti Guru dan Pembina Pramuka.

\subsection{SARAN}

Setelah melalui proses panjang sampai perancangan media pembelajaran ini selesai, peneliti tidak menutup kemungkinan ada beberapa kekurangan, namun dengan proses yang sudah peneliti lalui, ada beberapa saran yang peneliti tujukan bagi guru ataupun lembaga pendidikan, serta para designer.

1. Bagi guru/lembaga pendidikan, jangan mementingkan aspek kognitif saja dan kurang memandang persoalan motivasi belajar siswa. Sebagai tenaga pengajar harus lebih peka mengidentifikasi penyebab masalah dalam pembelajaran mengenai kurangnya motivasi belajar siswa.

2. Bagi Designer terkhusus mahasiswa DKV, diharapkan memperbanyak data saat akan merancang sesuatu, memperhatikan elemen-elemen yang akan digunakan seperti tipografi, warna dan segala bentuk visual lainnya apakah sudah sesuai dengan target audience atau pemecahan masalah yang ditawarkan.

\section{DAFTAR PUSTAKA}

Alvyanto. (2010). Kurikulum Tingkat Satuan Pendidikan (KTSP) (online).

Ariyanti, D. Y. (2015). Pengembangan Komik Matematika Sebagai Media Pembelajaran Berbasis Pendidikan Karakter pada Materi Perkalian
Bilangan Bulat Sekolah Dasar. Jurnal Ilmiah Edukasi Matematika (JIEM) 23 Vol. 1/No.1/April 2015 ISSN: 9772442-8780-11.

Arsyad, A. (2013). Media Pembelajaran. Jakarta: Rajawali Pers.

Arulan, D. B. (2013). Media Komik Matematika Dalam Meningkatkan Pemahaman Materi Perkalian Pada Siswa Kelas 3 Minurul Huda Malang. Malang.

Dameria, A. (2007). Color Basic. Jakarta: Link \& Match Graphic.

K, M. E. (2015). Tugas Akhir Perancangan Komik Sejarah Perkembangan Desain Grafis Indonesia. UPT PERPUSTAKAAN ISI YOGYAKARTA.

Kusmiati, Artini dkk. (1999). Teori Dasar Desain Komunikasi Visual. Jakarta: Djambatan.

Lajamuddin, A. B. (2005). Analisis dan Desain Sistem Imformasi. Jakarta: Graha Ilmu.

Lestari, S. S. (2009). Media Grafis: Media Komik.

McCloud, S. (2008). Understanding Comics. Jakarta: Kepustakaan Populer Gramedia.

Muhson, A. (2010). Pengembangan Media Pembelajaran Berbasis Teknologi Informasi. Jurnal Pendidikan Akuntansi Indonesia Vol. VIII. No.2.

Putra, G. L. (2011). Perancangan Media Komunikasi Visual Sebagai Sarana Promosi SD Saraswat 2 Denpasar.

Rustan, Surianto. (2009). Layout. Jakarta: PT. Gramedia Pustaka Utama.

Rustan, Surianto. (2011). Font Tipografi. Jakarta: PT. Gramedia Pustaka Utama. Sadiman, Arif S, Rahardjo R, Haryono, Anung, Rahardjito. (2009). Media

Pendidikan, pengertian, pengembangan, dan pemanfaatannya. Jakarta: Rajawali Pers. 